\title{
METODE SERVQUAL DAN IMPORTANCE PERFORMANCE ANALYSIS UNTUK ANALISA KUALITAS LAYANAN JASA PENDIDIKAN TINGGI PADA MAHASISWA DI CIREBON
}

\author{
Chandra Lukita', Sudadi Pranata ${ }^{2}$, Kiran Agustin ${ }^{3}$ \\ Sekolah Tinggi Manajemen Informatika dan Komputer CIC Cirebon \\ J1. Kesambi 202, Kota Cirebon, Jawa Barat. Telp: (0231) 220250 \\ E-mail: chandralukita@yahoo.com ${ }^{1}$
}

\begin{abstract}
Abstrak
Penelitian dengan judul "Metode Servqual dan Importance Performance Analysis Untuk Analisa Kualitas Layanan Jasa Pendidikan Tinggi Pada Mahasiswa di Cirebon”.Maksud dan tujuan dari penelitian tersebut adalah untuk mengetahui bagaimana kinerja dan kualitas layanan jasa pendidikan tinggi di Cirebon. Pengambilan data menggunakan teknik wawancara dan menyebarkan kuesioner, banyaknya sample sebesar 200 responden yang terdiri dari mahasiswa di Cirebon.Data - data lain yang diperoleh dari hasil observasi, wawancara, dan studi pustaka. Penelitian ini menganalisis kinerja pada masing-masing Perguruan Tinggi dan menghitung tingkat kepuasan mahasiswa dengan serangkaian pengujian dalam analisis data. Metode yang digunakan adalah Metode Service Quality (Servqual Gap 5) dan Importance Performance Analysis dengan sebelumnya diuji dengan Uji Validitas dan Uji Reliabilitas. Dari hasil penelitian, diperoleh data yang menyatakan hasil dari metode servqual rata-rata keseluruhan gap per dimensi, dapat diketahui bahwa dimensi bukti fisik yang memenuhi harapan mahasiswa dengan gap = 0, dan sisanya yaitu Empati, Kehandalan, Daya Tanggap dan Asurance memiliki gap negatif, dengan kehandalan dan daya tanggap sebesar -0,3, empati -0.2 dan asurance -0,1. Dan tingkat kesesuaian rata-rata sebesar 96 pada perhitungan menggunakan metode Importance Performance Analysis menunjukkan bahwa kualitas pelayanan jasa pendidikan tinggi di Cirebon yaitu Sangat Baik.
\end{abstract}

Katakunci: Kualitas Pelayanan, Servqual, Kepuasan Mahasiswa, Importance Performance Analysis

Research with the title "Servqual Method and Importance Performance Analysis for Quality Analysis of Higher Education Services in Students in Cirebon. The purpose and purpose of the research is to find out how the performance and quality of higher education services in Cirebon. Retrieval of data using interview techniques and distributing questionnaires, the number of samples of 200 respondents consisting of students in Cirebon. Other data obtained from observations, interviews, and literature study. This study analyzes the performance of each university and calculates the level of student satisfaction with a series of tests in data analysis. The method used is the Service Quality Method (Servqual Gap 5) and the Importance Performance Analysis previously tested with the Validity Test and Reliability Test. From the results of the study, obtained data that states the results of the average servqual method of the overall gap per dimension, can be seen that the dimensions of physical evidence that meet the expectations of students with a gap $=0$, and the rest, namely Empathy, Reliability, Responsiveness and Assurance has a negative gap, with reliability and responsiveness of -0.3, empathy - 0.2 and asurance -0.1. And the suitability level of an average of 96 in calculations using the Importance Performance Analysis method shows that the quality of higher education services in Cirebon is Very Good.

Keywords:Service Quality, Servqual, Student Satisfaction, Importance Performance Analysis 


\section{PENDAhuluan}

Perkembangan dunia pendidikan saat ini telah membawa para pelaku dunia pendidikan khususnya di perguruan tinggi kepada persaingan yang sangat ketat, perguruan tinggi sebagai institusi penyelenggara pendidikan tinggi merupakan salah satu industri jasa penting, karena tidak hanya sekedar menyelenggarakan jasa pendidikan tetapi juga harus berusaha dapat memenuhi harapan mahasiswa yang melanjutkan studi dengan tujuan dapat mengembangkan potensi dirinya supaya mampu bersaing dalam dunia kerja (Lechter, 2005).

Menurut Cronin (1992) ada hubungan yang signifikan positif antara kualitas pelayanan dan kepuasan pelanggan dimana memiliki pengaruh terhadap keputusan untuk melakukan transaksi ulang. Artinya adalah ketika seorang mahasiswa membuat sebuah keputusan memilih sebuah perguruan tinggi sebagai tempat studi lanjutnya maka mahasiswa tersebut percaya dan mencari kualitas layanan yang dijanjikan diberikan oleh perguruan tinggi yang dipilihnya, dan sebagai institusi pendidikan tinggi harus menyadari bahwa salah satu cara untuk tetap dapat bersaing unggul adalah berupaya konsisten dan berkelanjutan dapat memberikan jasa pendidikan dengan kualitas yang lebih baik dari pesaingnya, karena pelanggan yang puas terhadap kualitas layanan yang didapatnya, dalam hal ini adalah mahasiswa atau alumni, mau merekomendasikan kepada orang lain untuk juga melanjutkan studi di tempatnya memperoleh pengalaman kepuasan layanan pendidikan tersebut.

Lebih lanjut mengacu pada apa yang disampaikan Parasuraman dan Berry (dalam Jamiluddin, 2013) menyatakan bahwa kualitas pelayanan merupakan dasar dari pemasaran jasa, penekanannya pada pemasaran "4P" yaitu product, price, promotion, dan place. Dalam usaha yang bergerak pada bidang jasa tidak satupun dari keempat $\mathrm{P}$ tersebut akan berjalan dengan baik tanpa Q (Quality). Oleh karena itu, perguruan tinggi harus membuat perencanaan yang tepat untuk menghadapi persaingan yang kompetitif ini, yaitu dengan cara menciptakan dan meningkatkan kualitas pelayanan yang dimiliki. Ada tiga macam penilaian kualitas jasa berdasarkan perspektif konsumen (Parasuraman, et.al 1985). Pertama, kualitas jasa dinilai baik atau positif apabila jasa yang dipersepsikan sesuai dengan harapan konsumen. Kedua, kualitas jasa dinilai ideal jika jasa yang dipersepsikan melebihi 4 harapan konsumen. Ketiga, kualitas jasa dinyatakan kurang baik apabila jasa yang dipersepsikan lebih jelek dibandingkan harapan konsumen.

Adanya pelayanan yang baik, baik dari sudut pandang Perguruan Tinggi maupun dari mahasiswa maka akan menciptakan suatu kondisi yang berimbang dan tentunya akan berdampak positif bagi Perguruan Tinggi dan mahasiswa. Untuk indikator kualitas pelayanan yang lain, yaitu bukti langsung (tangible), kehandalan (reliability), daya tanggap (responsiviness), jaminan (assurance) dan empati (emphaty).

Di Provinsi Jawa Barat, khususnya di Cirebon terdapat 23 Perguruan Tinggi. Dari pengamatan yang dilakukan peneliti sebelumnya dari 23 perguruan tinggi yang terletak di Cirebon tersebut dapat ditemukan beberapa faktor tentang kepuasan pelayanan yang dirasakan oleh mahasiswa seperti fasilitas penunjang yang kurang memadai, atau staff administasi yang kurang sungguh-sungguh saat melayani mahasiswanya. Kemudian untuk memperkuat metodologi penelitian yang ada, peneliti mengambil sample dari perguruan tinggi yang ada di kota Cirebon.

Peneliti menggunakan instrumen servqual yang diciptakan Parasuraman, Zeithml, dan Berry. Model kualitas layanan ini paling populer dan hingga kini banyak dijadikan acuan dalam riset manajemen, dan dalam perkembangannya model SERVQUAL ini juga dijadikan acuan untuk mengukur kualitas layanan yang lebih spesifik dibidang jasa pendidikan (Tjiptono, 2011:235). SERVQUAL merupakan metode yang digunakan untuk mengukur kualitas layanan berdasarkan bagaimana persepsi pelanggan dan harapan pelanggan terhadap pelayanan yang diberikan kepada mahasiswa di Cirebon. Alasan pemilihan metode ini dibandingkan dengan metode lain karena metode ini merupakan salah satu metode yang sering digunakan dalam melakukan pengukuran kualitas layanan yang dirasa sering digunakan dalam melakukan pengukuran kualitas layanan.

\subsection{Identifkasi Masalah}

Berdasarkan latar belakang masalah diatas maka penulis membuat identifikasi masalah yang akan menjadi bahasan yaitu sebagai berikut:

1. Bagaimanakah kualitas pelayanan pendidikan yang diberikan Perguruan Tinggidi Cirebon?

2. Bagaimanakah kesenjangan antara persepsi dan harapan mahasiswa terhadap kualitas pelayanan pendidikan Perguruan Tinggidi Cirebon? 
3. Atribut-atribut pelayanan apa sajakah yang dianggap penting oleh mahasiswa sesuai dengan dimensi TERRA.

\subsection{Tujuan Penelitian}

Adapun yang menjadi tujuan dari penelitian yang akan dilakukan adalah :

1. Untuk menganalisis kualitas pelayanan pendidikan yang diberikan Perguruan Tinggi di Cirebon.

2. Untuk mengetahui kesenjangan antara persepsi dan harapan mahasiswa terhadap kualitas pelayanan pendidikan di Perguruan Tinggi di Cirebon.

3. Untuk mengindentifikasi faktor kualitas layanan apa yang dianggap penting dengan menggunakan dimensi TERRA .

\section{KAJIAN PUSTAKA}

\subsection{Pengertian Jasa dan Kualitas Jasa}

Menurut Kotler (Dalam Lupiyoadi, 2006:6) "Setiap tindakan atau kegiatan yang dapat ditawarkan oleh suatu pihak kepada pihak lain, pada dasarnya tidak berwujud dan tidak mengakibatkan kepemilikian apapun. Produksi jasa bisa berkaitan dengan produk fisik atau sebaliknya". Menurut Valerie A. Zeithml dan Mary Jo Bitner (1996) dalam (Lupiyoadi, 2006:6) mendefinisikan jasa adalah semua aktifitas ekonomi yang hasilnya bukan berbentuk produk fisik atau konstruksi, yang umumnya dihasilkan dan dikonsumsi secara bersamaan serta memberikan nilai tambah (misalnya kenyamanan, hiburan, kesenangan, atau kesehatan konsumen).

Mahasiswa sebagai konsumen yang menikamati jasa yang seharusnya menentukan kualitas jasa, persepsi mahasiswa terhadap kualitas jasa merupakan penilaian menyeluruh atas keunggulan suatu jasa dan sudut pandang konsumen. Namun perlu diperhatikan bahwa sifat jasa yang tidak nyata menyebabkan sangat sulit bagi konsumen untuk menilai jasa sebelum dia mengalami bahkan setelah dia konsumsi jasa tertentupun sulit bagi pelanggan untuk menilai kualitas jasa tersebut. (Jasfar, 2009).

\section{a. Karakteristik Jasa}

Menurut Menurut Fandy Tjiptono (2011: 331), kualitas pelayanan berfokus pada upaya pemenuhan kebutuhan dan keinginan pelanggan serta ketepatan penyampaiannya untuk mengimbangi harapan pelanggan. Untuk memperoleh gambaran pemahaman tentang kualitas jasa, maka perlu mengetahui empat karakteristik yang mempengaruhi desain program pemasaran jasa menurut Kotler dan Keller (2009: 39) diantaranya:

a) Jasa tak berwujud (intangibility), jasa tidak dapat dilihat, dirasakan, diraba, didengar sebelum jasa itu di beli.

b) Jasa tak terpisahkan (inseparability), jasa tidak dapat dipisahkan dari penyedianya, tanpa mempedulikan apakah penyedia jasa itu orang atau mesin karena pelanggan juga hadir pada saat jasa itu diproduksi, interaksi penyedia jasa dan pelanggan menjadi fitur khusus pemasaran jasa.

c) Bervariasi (variability), kualitas jasa bergantung pada siapa yang menyediakan jasa itu dan kapan, dimana, dan bagaimana.

d) Dapat musnah (perishability), jasa tidak dapat disimpan untuk dijual atau digunakan beberapa saat kemudian.

b. Kualitas pelayanan jasa

Definisi kualitas jasa berpusat pada upaya pemenuhan kebutuhan dan keinginan pelanggan serta ketepatan penyampaiannya untuk mengimbangi harapan pelanggan. Ada dua faktor utama yang mempengaruhi kualitas jasa, yaitu expected service dan perceives service (Parasuraman, et al., 1985 dalam Tjiptono, 2002). Apabila jasa yang diterima atau dirasakan sesuai dengan yang diharapkan, maka kualitas jasa yang dipersepsikan baik dan memuaskan.Jika jasa yang diterima melampaui harapan pelanggan, maka kualitas jasa dipersepsikan sebagai kualitas yang ideal.Sebaliknya jika jasa yang diterima lebih rendah dari pada yang diharapkan maka kualitas jasa tergantung pada kemampuan penyedia jasa dalam memenuhi harapan pelanggannya secara konsisten (Herlina, 2010: 31).

Menurut Kotler (dalam Tjiptono 2002) kualitas harus dimulai dari kebutuhan pelanggan dan berakhir pada persepsi pelanggan.Hal ini berarti bahwa citra kualitas yang baik bukanlah 
berdasarkan sudut pandang atau persepsi pihak penyedia jasa, melainkan berdasarkan sudut pandang atau persepsi pelanggan, sehingga merekalah yang seharusnya menilai kualitas jasa. Kualitas suatu barang umumnya cenderung dilihat oleh mahasiswa dari kesesuaian barang baik itu manfaat, daya tahan, dan faktor lain dengan spesifikasi barang yang ditawarkan oleh suatu perusahaan (Tjiptono, 2002).

c. Dimensi kualitas jasa

Pada prisipnya, definisi kualitas jasa berfokus pada upaya pemenuhan kebutuhan dan keinginan pelanggan serta ketepatan penyampaian untuk mengimbangi harapan pelanggan.Kualitas jasa harus dimulai dari kebutuhan pelanggan dan berakhir dengan kepuasan pelanggan (Kotler, 2000: 52).Sebagai pihak yang membeli dan mengkonsumsi jasa, pelangganlah yang menilai tingkat kualitas jasa sebuah perusahaan.

Karena jasa tidak kasat mata serta kualitas teknik jasa tidak selalu dapat dievaluasi secara akurat, pelanggan berusaha menilai kualitas jasa berdasarkan apa yang dirasakannya yaitu atributatribut yang mewakili kualitas pelayanan (Rangkuti, 2008:29). Berkaitan dengan apa yang menjadi dimensi atau unsur-unsur dari service quality, berdasarkan hasil penelitian tentang Delivering Quality Service:Balancing Custumer Perceptions And Expectation, (Parasuraman, et.al 1988) memperoleh hasil bahwa terdapat sepuluh dimensi umum kualitas pelayanan, yaitu: (Parasuraman, et.al dalam Tjiptono, 2004): Reliability, responsiveness, competence, Access, Courtesy, Communication, Credibility, Security, Understanding, Tangibles.

Dalam perkembangan selanjutnya, yaitu pada tahun 1988, Parasuraman dan kawan-kawan (dalam Sukma Pratiwi 2011: 37) menemukan bahwa sepuluh dimensi yang ada dapat dirangkum menjadi lima dimensi pokok yaitu: tangible, reliability, responsiveness, assurance, dan emphaty. Kelima dimensi tersebut adalah merupakan suatu skala multi item yang dinamakan SERVQUAL, yang diperlukan untuk mengukur kualitas jasa atau kualitas pelayanan, meliputi:

a) Bukti Fisik (tangible) meliputi penampilan fisik, peralatan, petugas, dan materi komunikasi.

b) Reabilitas (reliability), berkaitan dengan kemampuan instansi untuk memberikan layanan yang akurat sejak pertama kali tanpamembuat kesalahan apapun dan menyampaikan jasanya sesuai dengan waktu yang disepakati.

c) Daya tanggap (responssiveness), berkenaan dengan kesediaan dan kemampuan dosen dan karyawan program studi untuk membantu mahasiswa dan merespon permintaan mahasiswa, serta menginformasikan kapan saja akan diberikan dan kemudian memberikan jasa secara cepat.

d) Jaminan (assurance), yakni perilaku dosen maupun karyawan mampu menumbuhkan kepercayaan mahasiswa terhadap program studi, bisa menciptakan rasa aman bagi mahasiswa. Jaminan juga berarti bahawa para karyawan selalu bersikap sopan dan menguasai pengetahuan dan keterampilan yang dibutuhkan untuk menangani setiap pertanyaan dan masalah mahasiswa.

e) Empati (emphaty), Program studi Pendidikan Ekonomi mampu memahami masalah mahasiswa dan bertindak demi kepentingan mahasiswa, serta memberikan perhatian personal kepada mahasiswa dan memiliki jam operasi yang nyaman.

Berry et al (1985 dalam Herlina, 2010:33) mengemukakan bahwa kualitas jasa atau pelayanan yang bisa diamati oleh konsumen merupakan hasil dari perbandingan konsumen atas layanan yang diharapkan dengan layanan yang didapat (dirasakan).

\subsection{Definisi Pelayanan Pendidikan}

Pendidikan menurut Crow (dikutip dari Rini Indah, 2011:4) adalah proses yang berisi berbagai macam kegiatan yang sesuai dengan kegiatan seseorang untuk kehidupan sosialnya dan membantu kebiasaan-kebiasaan dan kebudayaan serta kelembagaan sosial dari generasi ke generasi.

Berdasarkan definisi di atas, dapat disimpulkan bahwa pokok-pokok penting pendidikan adalah: (1) Pendidikan merupakan proses yaitu proses pembelajaran, proses sosial dan proses memanusiakan manusia, (2) Pendidikan mengubah dan mengembangkan kemampuan, sikap dan perilaku. Berdasarkan hal ini dapat dikatakan bahwa pendidikan bukan hanya tranfer pengetahuan (transfer of knowledge) tetapi seluruh rangkaian kegiatan untuk memanusiakan manusia yang mampu mengembangkan kemampuannya. 
Mengukur kualitas layanan pendidikan di perguruan tinggi di era kompetitif ini adalah menjadi hal yang semakin penting, dan hal utama yang harus diperhatikan dalam mengukur kualitas layanan pendidikan tinggi tergantung pada bagaimana terlebih dahulu dapat mengidentifikasi aspek-aspek penting apa saja yang harus ada dalam layanan. Dalam mengukur kualitas layanan, kenyataannya lebih sulit dibandingkan mengukur kualitas suatu produk karena bersifat tidak terlihat dan tidak bisa diraba. Namun demikian menurut Zeithaml (1990) dalam Rosi (2015) banyak peneliti yang berpendapat bahwa kualitas layanan dapat diukur dengan membuat perbandingan antara apa yang menjadi harapan dan apa yang menjadi persepsi konsumen.

Mengukur proses pendidikan tinggi melalui penilaian internal secara berkala dari para mahasiswa merupakan hal yang penting karena penilaian secara periodik ini dapat menjadi bagian dari upaya peningkatan kualitas program dan perbaikan sumber daya secara terus menerus. Terlepas dari masih adanya perbedaan definisi kualitas layanan dan bagaimana cara mengukurnya, kualitas layanan dalam lingkup pendidikan tinggi tidak hanya sekedar mencakup komponen layanannya saja, namun juga termasuk dalam kualitas inputnya yaitu meliputi mahasiswa, dosen, staff administrasi pendukung dan juga kualitas proses dalam bentuk kegiatan belajar mengajar.

Menurut Fandy Tjiptono (2011: 331), kualitas pelayanan berfokus pada upaya pemenuhan kebutuhan dan keinginan pelanggan serta ketepatan penyampaiannya untuk mengimbangi harapan pelanggan, sehingga pelayanan pendidikan dalam penelitian ini adalah pelayanan yang diberikan oleh dosen dalam pembelajaran serta pelayanan administrasi akademik oleh staf perguruan tinggi.

\subsection{Definisi Kepuasan Mahasiswa}

Fokus dari kualitas suatu pelayanan adalah kepuasan pelanggan, oleh karena itu perlu dipahami terlebih dahulu komponen-komponen yang berkaitan dengan kepuasan pelanggan, yang dalam hal ini adalah mahasiswa. Pada dasarnya kepuasan pelanggan dapat didefinisikan secara sederhana, yaitu sebagai suatu keadaan saat kebutuhan dan harapan pelanggan dapat terpenuhi melalui produk atau jasa yang dikonsumsi.

Terdapat beberapa definisi kepuasan pelanggan, diantaranya pendapat kepuasan menurut Oliver dalam Barnes (2003: 64) mendefinisikan tanggapan pelanggan atas terpenuhinya kebutuhan yang berarti bahwa penilaian pelanggan atas terpenuhinya kebutuhan yang berarti bahwa penilaian pelanggan atas barang atau jasa memberikan tingkat kenyamanan yang terkait dengan pemenuhan suatu kebutuhan, termasuk pemenuhan kebutuhan yang tidak sesuai harapan atau pemenuhan yang melebihi harapan.

Tjiptono (2012) menjelaskan bahwa kepuasan pelanggan bukanlah konsep absolut, melainkan relatif atau tergantung pada apa yang diharapkan pelanggan. Pelanggan yang merasa puas akan memberitahu orang lain tentang pengalaman mereka yang menyenangkan kepada orang lain, dan berpeluang besar untukkembali menggunakan jasa yang sama dimasa yang akan datang, dengan kata lain pelanggan yang baik akan menjadi iklan yang baik untuk produk jasa yang telah digunakannya.

Faktor-faktor yang mempengaruhi kepuasan pelanggan menurut Rambat Lupiyoadi (2001: 158) untuk menentukan tingkat kepuasan pelanggan terdapat 5 dimensi atribut faktor utama yang harus diperhatikan penyedia jasa, diantaranya:

a) Kualitas Produk

Pelanggan akan merasa puas bila hasil evaluasi mereka menunjukan bahwa produk yang merekagunakan berkualitas.

b) Kualitas Pelayanan

Dalam industri jasa, pelanggan akan merasa puas apabila mereka mendapatkan pelayanan yang baik atau sesuai dengan yang diharapkan.

c) Emosional

Dalam menggunakan produknya, pelanggan akan merasa bangga mendapatkan keyakinan bahwa orang lain akan kagum bila menggunakan produk dengan merek tertentu yang cenderung mempunyai nilai dan tingkat kepuasan yang lebih tinggi.

d) Harga

Produk yang mempunyai kualitas yang sama tetapi menetapkan harga yang relatif murah akan memberikan nilai yang lebih tinggi kepada pelanggannya.

e) Biaya 
Pelanggan yang tidak perlu mengeluarkan biaya tambahan atau tidak perlu membuang waktu untuk mendapatkan suatu produk atau jasa cenderung puas terhadap produk atau jasa itu.

Menurut Lupiyoadi dan Hamdani (2006: 192) dikatakan juga bahwa faktor utama penentu kepuasan pelanggan adalah persepsi pelanggan terhadap kualitas jasa. Sehingga kualitas pelayanan memiliki peranan penting yang harus diperhatikan dalam menciptakan kepuasan dan memiki efek positif yang signifikan terhadap kepuasan.

a. Pengukuran Kepuasan Pelanggan

Menurut Kotler (dalam Tjiptono, 2000), mengidentifikasi empat metode untuk mengukur kepuasan pelanggan, yaitu:

1) Sistem Keluhan dan Saran

Setiap organisasi yang berorientasi pada konsumen perlu memperhatikan kesempatan yang luas kepada para konsumennya untuk menyampaikan saran, pendapat, dan keluhan mereka.Media yang digunakan biasanya dengan menyediakan kotak saran, kartu komentar, dan lain-lain.

2) Ghost Shopping

Metode ini dilakukan dengan mempekerjakan beberapa orang untuk berperan sebagai pembeli produk perusahaan dan pesaing, kemudian melaporkan mengenai kekuatan dan kelemahan produk perusahaan dan pesaing berdasarkan pengalaman mereka dalam pembelian produk tersebut.

3) Survei Kepuasan Konsumen

Pengukuran kepuasan pelanggan dengan metode survey dapat dilakukan dengan berbagai cara, diantaranya:

a) Directly Reported Satisfaction

Pengukuran dilakukan dengan item-item spesifik yang menanyakan langsung tingkat kepuasan yang dirasakana pelanggan.

b) Derived Satisfaction

Pengukurran tingkat kepuasan pelanggan dengan cara mengajukan pertanyaan yang menyangkut tentang dua hal:

(1) Tingkat harapan atau ekspektasi pelanggan terhadap kinerja pada atribut-atribut relevan.

(2) Persepsi pelanggan terhadap kinerja aktual.

4) Importance-Performance Analysis

Teknik ini meminta responden untuk menilai tingkat kepentingan berbagai atribut relevan dan tingkat kinerja perusahaan pada masing-masing atribut tersebut. Kemudian, nilai ratarata tingkat kepentingan atribut dan kinerja perusahaan akan dianalisis di ImportancePerformance Matrix.

Kepuasan pelanggan merupakan dampak dari perbandingan antara harapan dan kenyataan yang diperoleh dari pelanggan. Apabila kinerja jasa lebih baik dari yang diharapkan, maka pelanggan merasa puas, jika kenyataan lebih buruk dari apa yang diharapkan, maka pelanggan akan merasa kecewa dan tidak puas. Perbandingan antara kenyataan dan harapan untuk mengukur kepusan pelanggan salah satunya terdapat dalam SERVQUAL rumusan Parasuraman (1998) yang digunakan dalam penelitian ini.

\subsubsection{Hasil Penelitian Terdahulu}

1. Penelitian Deny Wibisono (2018), tentang: "Analisis Kualitas Layanan Pendidikan Dengan Menggunakan IntegrasiMetodeServqual DanQFD”, dengan kesimpulan sebagai berikut :

a) Faktor-faktor yang mempengaruhi kepuasan siswa terhadap pelayanan pendidikan di SMA YASPORBI setelah dilakukan observasi dan diskusi dengan pihak sekolah berkaitan dengan 5 dimensi kualitas pelayanan, yaitu tangibles (bukti langsung), reliability (kehandalan), responsiveness (daya tanggap), assurance (jaminan) dan emphaty (empati) diperoleh 32 butir atribut yang dapat mempengaruhi kepuasan siswa terhadap pelayanan pendidikan.

b) Atribut - atribut pelayanan pendidikan yang mempunyai nilai gap score negatif dan ada 21 atribut pelayanan pendidikan yang mempunyai nilai positif. Untuk ke 11 atribut pelayanan 
pendidikan yang mempunyai nilai gap score negatif perlu mendapatkan perhatian dan perbaikan, sehingga dibutuhkan langkah-langkah perbaikan yang dijabarkan dalam analisa $Q F D$. Atribut pelayanan pendidikan yang perlu dilakukan perbaikan, diantaranya adalah:

1) Guru mampu menyampaikan materi pelajaran dengan baik

2) Peraturan sekolah berlaku untuk semua siswa

3) Terbina komunikasi yang baik antara siswa dengan guru dan karyawan

4) Guru bersikap adil terhadap seluruh siswa

5) Guru memberikan perhatian kepada siswa yang belum mengerti materi yang diajarkan

6) Guru mudah ditemui apabila ada siswa yang ingin berkonsultasi tentang pelajaran yang belum dimengerti

7) Guru selalu memberikan motivasi siswa untuk terus belajar

8) Proses belajar mengajar yang mudah dipahami dan dimengerti

9) Karyawan mampu melayani orang tua dengan baik

10) Guru membantu siswa dengan segera terhadap materi yang belum dimengerti

11) Guru menjawab dengan segera pertanyaan dari siswa apabila terdapat pertanyaan dan kesulitan

2. Penelitian Luthfi Nugraha, Yuniar, Ambar Harsono (2015), tentang "Usulan Peningkatan Kualitas Pelayanan Jasa Pendidikan Bahasa Inggris Menggunakan MetodeService Quality (SERVQUAL) Di LBPP LIA Martadinata Kota Bandung", maka dapat ditarik kesimpulan sebagai berikut :

a. Terdapat 20 atribut pelayanan jasa yang bernilai negatif pada perhitungan Gap 5. Hal ini menunjukkan bahwa konsumen merasa tidak puas terhadap pelayanan yang diberikan oleh pihak lembaga, sebab masih terdapat kesenjangan antara ekspektasi dengan persepsi konsumen.

b. Terdapat 10 atribut bernilai negatif pada perhitungan Gap 1, diantaranya atribut nomor 1,2,3,6,8,12,13,14,17,20. Hal ini menunjukkan bahwa ketidakpuasan konsumen terhadap 10 atribut tersebut disebabkan oleh pihak manajemen tidak mengetahui ekspekstasi konsumen.

c. Pada perhitungan Gap 2 tidak ditemukan atribut bernilai negatif, artinya perusahaan telah memiliki standar atau spesifikasi kualitas pelayanan yang sesuai dengan ekspektasi konsumen.

d. Terdapat 10 atribut bernilai negatif pada perhitungan Gap 3, diantaranya atribut nomor $4,5,7,9,10,11,15,16,18,19$. Hal ini menunjukkan bahwa ketidak puasan konsumen terhadap 10 atribut tersebut disebabkan oleh penyampaian pelayanan yang diberikan tidak sesuai dengan standar atau spesifikasi yang telah ditetapkan.

e. Pada perhitungan Gap 4 terhadap 3 atribut yang dikomunikasikan secara eksternal, menunjukkan bahwa 3 atribut tersebut bernilai negatif. Hal ini menunjukkan bahwa kualitas pelayanan yang dijanjikan dan dikomunikasikan secara eksternal belum sesuai.

f. Secara keseluruhan peserta didik berdasarkan klasifikasi kelas sudah merasa puas terhadap atribut kualitas pelayanan nomor 13 yaitu pengajar bersikap ramah dan sopan terhadap peserta didik.

3. Penelitian Lissa Rosdiana Noer (2016), tentang "Analisis Peningkatan Kualitas Pelayanan Mahasiswa Magister Manajemen Teknologi ITSSurabaya Dengan MetodeServqualDanImportance Performance Analysis(IPA)", ditarik kesimpulan sebagai berikut :

a) Variabel pelayanan Prodi berdasarkan metode Servqual, terdapat lima variabel yang memiliki nilai gap tertinggi, yaitu pertama variabel Tangible 7 sebesar 1,9 yaitu fasilitas wifi/internet cepat. Kedua adalah variabel Tangible 8 sebesar 1,25 yaitu toilet bersih. Ketiga adalah variabel reliability 1 sebesar 1,15 yaitu penyampaian informasi akademik cepat. Keempat adalah variabel tangible 5 sebesar 1,12 yaitu tempat parkir mobil memadai. Terakhir adalah variabel emphaty 4 sebesar 1,07 yaitu adanya kotak saran untuk menampung keluhan dan dapat menyelesaikan keluhan mahasiswa. Sehingga dapat disimpulkan bahwa variabel yang lebih dominan dari kelima variabel tertinggi tersebut adalah variabel tangible.

b) Berdasarkan hasil pengintegrasian Metode Servqual dan IPA. Variabel yang perlu ditingkatkan oleh Prodi MMT-ITS diantaranya adalah tempat parkir motor, kesigapan petugas kebersihan, kemudahan mahasiswa menyampaikan keluhan sarana dan prasarana, kesigapan Satpam mengatur parkir dan keamanan (Prioritas utama/KuadranI). Pertahankan prestasi/kuadaran II antara lain: informasi akademik cepat, literatur buku/referensi/jurnal 
memadai, materi perkuliahan diterima dengan baik, akses jurnal online mudah dan cepat, kelas pengganti apabila dosen tidak hadir, keluhan mahasiswa ditanggapi dengan cepat, kemudahan mahasiswa menyampaikan keluhan akademik, kondisi meja dan kursi baik, ruangan kelas bersih, karyawan memberikan informasi perkuliahan, kejelasan informasi pembayaran kuliah dan kegiatan lainnya, jaminan kerahasiaan data mahasiswa, pencahayaan ruang terang, mahasiswa merasa aman, karyawan bersikap ramah, karyawan bersikap sopan, dan suhu ruangan sejuk. Variabel yang tidak kalah penting adalah fasilitas wifi/internet cepat dan toilet bersih (Tingkat kepuasan tinggi/Kuadran IV).

\section{METODOLOGI PENELITIAN}

\subsection{Jenis Penelitian, Variabel Penelitian, Populasi, dan Sampel}

Jenis penelitian yang digunakan adalah observasi dengan metode survei, untuk menjelaskan hubungan antara variabel terikat dengan variabel bebas dengan pendekatan kuantitatif.Variabel Terikat (Y) berupa Kualitas layanan jasa pendidikan dalam hal kepuasan Mahasiswa Perguruan Tinggi di Cirebon, Variabel Bebas (X)Harapan mahasiswa diukur berdasarkan dimensi TERRA; Tangible (wujud / tampilan), Empathy (perhatian), Responsiveness (daya tanggap), Reliability (keandalan), Assurance (jaminan). Dalam hal penelitian ini populasinya adalah total Mahasiswa di Cirebon yaitu sebanyak 26.259 orang Setelah dilakukan perhitungan dengan aplikasi sample size calculator dengan populasi 26259 pada tingkat confiden $80 \%$ dan tingkat precision 0.05 maka diperoleh jumlah sampel sebesar 181 responden dan dalam hal ini dibulatkan menjadi 200 sampel.

\subsection{Teknik Pengumpulan Data, Uji Instrumen Penelitian, dan Analisis}

Kuesioner yang berupa pertanyaan disebarkan kepada responden sesuai dengan permasalahan yang diteliti untuk memperoleh data yang berupa pernyataan responden mengenai variabel kinerja dan kepentingan. Dikarenakan sampel yang sulit di temui, sebagian dari pengumpulan data dilakukan dengan koesioner online menggunakan google form. Untuk mengetahiu alat ukur yang mampu memberikan informasi seperti apa yang diharapkan sehingga tingginya suatu alat ukur dapat dilihat dari nilai validitas dan reliabilitasnya. Sehingga dilakukan uji validitas dan uji reliabilitas. Untuk menjawab perumusan masalah mengenai apakah ada kesenjangan antara persepsi konsumen terhadap harapan konsumen, maka digunakan metode Service Quality (Servqual) dan Importance Performance Analysis (IPA) Metode ini diperlukan untuk mengukur tingkat kesesuaian dan mengetahui seberapa besar pelanggan merasa puas terhadap kinerja perusahaan, serta seberapa besar pihak penyedia jasa memahami apa yang diinginkan pelanggan terhadap jasa yang mereka berikan.

\section{HASIL DAN PEMBAHASAN}

\subsection{Perhitungan Gap Analisis dengan Metode Servqual}

Tabel 1Rata - rata Keseluruhan Gap Performance-Importance (Gap P-I) Kualitas Layanan Jasa Pendidikan Tinggi di Cirebon

\begin{tabular}{|c|l|c|c|c|}
\hline No & \multicolumn{1}{|c|}{ Dimensi } & $\begin{array}{c}\text { Mean } \\
\text { Performance }\end{array}$ & $\begin{array}{c}\text { Mean } \\
\text { Importance }\end{array}$ & Gap (P-I) \\
\hline $\mathbf{1}$ & Bukti Fisik (Tangible) & 4,1 & 4,1 & 0 \\
\hline $\mathbf{2}$ & Empati (Emphaty) & 3,9 & 4,1 & $-0,2$ \\
\hline $\mathbf{3}$ & Kehandalan (Reliability) & 3,8 & 4,1 & $-0,3$ \\
\hline $\mathbf{4}$ & Daya Tanggap (Responsiveness) & 3,8 & 4,1 & $-0,3$ \\
\hline $\mathbf{5}$ & Jaminan (Assurance) & 4 & 4,1 & $-0,1$ \\
\hline & RATA-RATA & $\mathbf{3 , 9 2}$ & $\mathbf{4 , 1}$ & $\mathbf{- 0 , 1 8}$ \\
\hline
\end{tabular}

Metode Servqual Dan Importance Performance Analysis Untuk Analisa Kualitas Layanan Jasa Pendidikan Tinggi Pada Mahasiswa Di Cirebon -(Chandra Lukita, Sudadi Pranata, Kiran Agustin) 
Berdasarkan tabel 4.1 adalah rata-rata keseluruhan gap per dimensi, dapat diketahui bahwa hanya dimensi bukti fisik yang memenuhi harapan mahasiswa dengan gap $=0$, dan sisanya yaitu Empati, Kehandalan, Daya Tanggap dan Jaminan memiliki gap negatif, dengan kehandalan dan daya tanggap sebesar -0,3, empati -0.2 dan jaminan -0,1.

Kemudian, untuk analisis gap P-I per item hampir sebagian atribut mendapat nilai negatif, ada dua atribut yang mendapat nilai positif, yaitu atribut pada dimensi tangibles pada Kebersihan, kelayakan dan kenyamanan ruang kelas yang mendapat nilai kesenjangan sebesar 0, dan pada dimensi jaminan Pelaksanaan konsultasi dan perwalian sesuai dengan waktu yang dijanjikan dengan kesenjangan 0,01. Sedangkan untuk kesenjangan tertinggi ada pada atribut Staff administrasi yang melayani mahasiswa dengan sungguh-sungguh yang mendapat nilai $-0,71$.

\subsection{Service Quality (Servqual)}

Model Servqual didasarkan pada asumsi bahwa konsumen membandingkan kinerja jasa pada atribut-atribut relevan dengan standar ideal/sempurna untuk masing-masing atribut jasa. Bila kinerja sesuai dengan atau melebihi standar, maka persepsi atas kualitas jasa keseluruhan akan positif dan sebaliknya. Dengan kata lain, model ini menganalisis gap antara dua variabel pokok, yakni jasa yang diharapkan (expected service) dan jasa yang dipersepsikan (perceived service). Pengukuran kualitas jasa dalam model Servqual didasarkan pada skala multi-item yang dirancang untuk mengukur harapan dan persepsi pelanggan, serta gap di antara keduanya pada lima dimensi utama kualitas jasa (reliabilitas, daya tanggap, jaminan, empati dan bukti fiksi). Kelima dimensi utama tersebut dijabarkan ke dalam masing-masing 20 atribut rinci untuk variabel harapan dan variabel persepsi, yang disusun dalam pernyataan-pernyataan berdasarkan skala Likert, dari 1 (Sangat Tidak Penting) sampai 5 (Sangat Penting).

\subsection{Importance Performance Analysis}

Tingkat kesesuaian harapan dan kinerja setelah dianalisis menunjukkan hasil antara 81\%-100\% yang mana menunjukkan hasil Sangat Baik, sedangkan dari berbagai penilaian responden terhadap atribut kualitas pelayanan diperoleh hasil bahwa semua atribut kinerja kualitas pelayanan memiliki nilai $96 \%$ berarti dalam hal ini kinerja kualitas layanan jasa pendidikan tinggi di Cirebon adalah Sangat Baik. Dengan demikian pihak Perguruan Tinggi Swasta di Cirebon dapat mempertahankan dan meningkatkan kinerjanya.

\subsection{TampilanAtarmukaBidder}

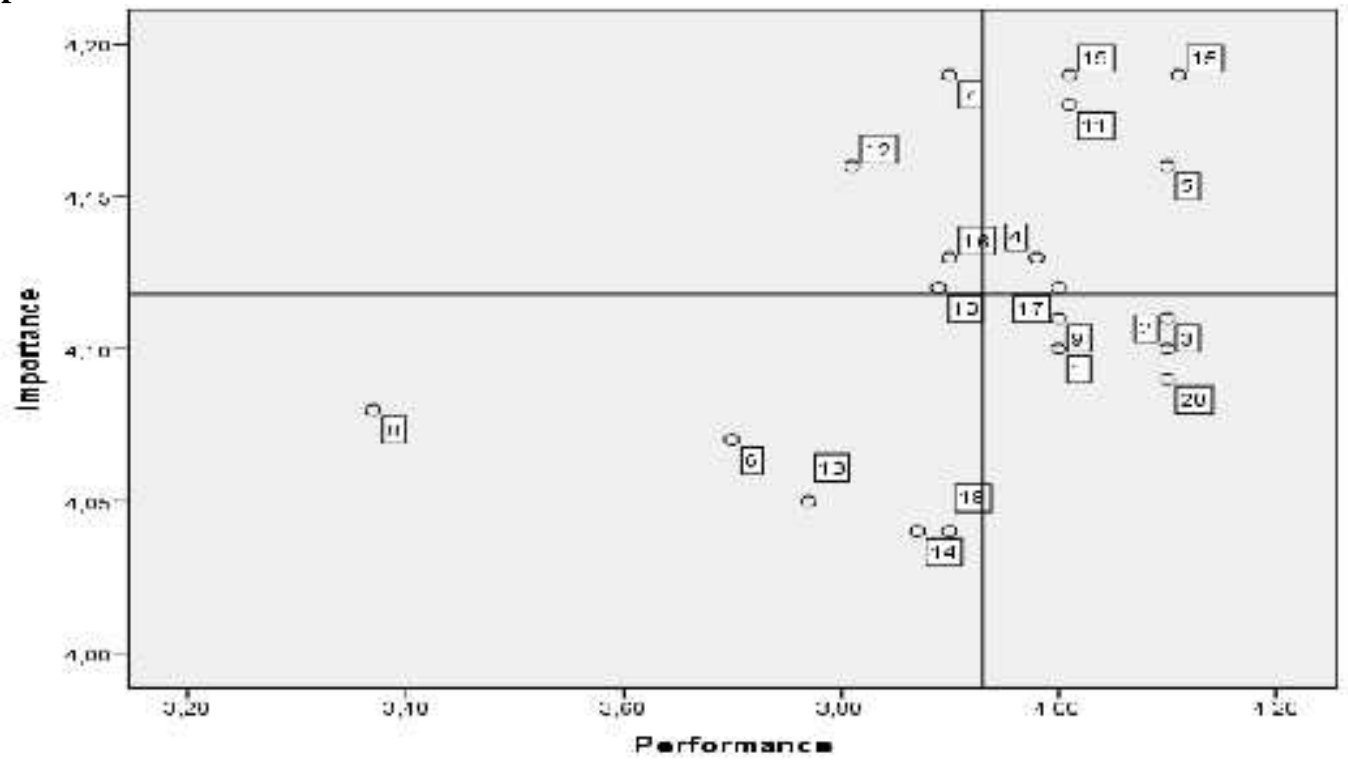

Gambar 1.Diagram Kartesius Kualitas Jasa Pendidikan Penilaian kuadran Importance Performance analysis untuk kualitas pelayanan 


\subsection{Hasil Analisis Kuadran}

a) Analisis Kuadran 1

Faktor pelayanan yang ada di kuadran ini adalah Kepedulian dosen apabila mahasiswa kesulitan memahami pelajaran (7), Materi yang disampaikan dosen sesuai program pembelajaran (10), Ketersediaan kesempatan bertanya dalam perkuliahan (12), dan Kejelasan dosen dalam memberikan materi kuliah (16). Artinya faktor pelayanan tersebut perlu diprioritaskan untuk ditingkatkan, karena harapan tinggi sedangkan realisasi tidak sesuai dengan harapan yaitu masih rendah.Faktor dikuadran ini dianggap sangat penting namun pihak Perguruan Tinggi belum melaksanakan sesuai keinginan Mahasiswa sehingga tidak memuaskan.

b) Analisis Kuadran 2

Faktor pelayanan yang ada di kuadran ini adalah Kelayakan fasilitas kampus (tempat parkir, tempat ibadah, dan toilet) (4), Keramahan dosen maupun staff administrasi (5), Kemampuan pelayanan staff administrasi secara profesional pada saat jam sibuk (11), Ketepatan waktu penyelesaian administrasi oleh petugas (15), Kejelasan dosen dalam memberikan materi kuliah (17), dan Ketepatan waktu penyampaian hasil studi (19). Faktor dikuadran ini dianggap sangat penting dan pelaksanaannya sangat memuaskan mahasiswa.

c) Analisis Kuadran 3

Faktor pelayanan yang ada pada kuadran ini adalah Kemudahan memperoleh informasi dari dosen maupun staff admin (6), Staff administrasi yang melayani mahasiswa dengan sungguhsungguh (8), Ketersediaan kesempatan bertanya dalam perkuliahan (13), Bimbingan dan konsultasi terkait kegiatan non akademik (14), dan Keamanan data kemahasiswaan terjamin (18). Artinya faktor faktor tersebut kurang penting pengaruhnya bagi mahasiswa, dianggap kurang prioritas dan kurang memuaskan.

d) Analisis Kuadran 4

Faktor pelayanan yang ada pada kuadran ini adalah Kerapihan penampilan dosen dan staff administrasi (1), Kebersihan,kelayakan dan kenyamanan ruang kelas (2), Kelengkapan fasilitas penunjang proses perkuliahan (white board, infokus,dll) (3), Ketepatan waktu dosen dalam menghadiri perkuliahan (9), Pelaksanaan konsultasi dan perwalian sesuai dengan waktu yang dijanjikan (20), yang terletak pada kuadran IV ini, artinya kurang penting mempengaruhi konsumen, akan tetapi pelaksanaannya berlebihan, dianggap kurang penting tetapi sangat memuaskan.

\section{KESIMPULAN DAN SARAN}

\subsection{Simpulan}

Berdasarkan hasil pembahasan tentang analisis kualitas layanan jasa pendidikan pada mahasiswa perguruan tinggi di Cirebon, maka dapat ditarik kesimpulan sebagai berikut :

1. Berdasarkan perhitungan dengan kedua metode tersebut dapat diketahui bahwa kualitas pelayanan jasa pendidikan perguruan tinggi di Cirebon dikategorikan Sangat Baik.

2. Berdasarkan perhitungan dengan metode servqual rata-rata keseluruhan gap per dimensi, dapat diketahui bahwa hanya dimensi bukti fisik yang memenuhi harapan mahasiswa dengan gap $=0$, dan sisanya yaitu Empati, Kehandalan, Daya Tanggap dan Asuransi memiliki gap negatif, dengan kehandalan dan daya tanggap sebesar -0,3, empati -0.2 dan asuransi -0,1.Kemudian, untuk analisis gap P-I per item hampir sebagian atributmendapat nilai negatif, ada dua atribut yang mendapat nilai positif,yaitu atribut pada dimensi tangibles pada Kebersihan, kelayakan dan kenyamanan ruang kelas yang mendapat nilai kesenjangan sebesar 0, dan pada dimensi assurance atau jaminanpelaksanaan konsultasi dan perwalian sesuai dengan waktu yang dijanjikan dengan kesenjangan 0,01. Sedangkan untuk kesenjangan tertinggi ada pada atribut Staff administrasi yang melayani mahasiswa dengan sungguh-sungguh yang mendapat nilai $-0,71$.

3. Berdasarkan perhitungan IPA yang telah dilakukan kualitas yang telah dilakukan secara keseluruhan kinerja kualitas pelayanan nilai rata-ratanya adalah 96 berarti dalam hal ini kinerja dan kualitas layanan jasa pendidikan pada perguruan tinggi di Cirebon adalah SANGAT BAIK. Dan atribut yang perlu ditingkatkan antara lain:

a. Kepedulian dosen apabila mahasiswa kesulitan memahami pelajaran 
b. Materi yang disampaikan dosen sesuai program pembelajaran

c. Ketersediaan kesempatan bertanya dalam perkuliahan

d. Kejelasan dosen dalam memberikan materi kuliah

\subsection{Saran}

Adapun saran saran yang dapat dikemukakan sehubungan dengan hasil yang telah peneliti lakukan berdasarkan analisis kuadran, maka peneliti menyarankan hal-hal yang perlu di prioritaskan dan harus ditingkatkan seperti:

1. Kepedulian dosen apabila mahasiswa kesulitan memahami pelajaran

2. Materi yang disampaikan dosen sesuai program pembelajaran

3. Ketersediaan kesempatan bertanya dalam perkuliahan

4. Kejelasan dosen dalam memberikan materi kuliah

\section{REFERENSI}

[1] Ronny, Toko Online DenganLK Sistem Lelang, Vol. I, eJournal Fakultas Teknologi Informasi Universitas Islam Kalimantan, 2013.

[2] Kotler Philip and Armstrong G. 2008. "Prinsip-Prinsip Dasar Pemasaran”. Jakarta: Erlangga.

[3] Kotler, Philip and Kervin Lane Keller. 2009. Marketing Management 13th Edition. (Alih bahasa: Bob Sabran). Jakarta: ERLANGGA.

[4] Prof. Dr. Sugiyono. 2013. METODE PENELITIAN KUANTITATIF, KUALITATIF DAN R\&D. Penerbit Alfabeta, CV. Bandung

[5] Rangkuti, F. 2002. Measuring Customer Satisfaction : Teknik Mengukur dan Strategi Meningkatkan Kepuasan Pelanggan, Jakarta: PT.Gramedia Pustaka Utama.

[6] Tjiptono, Fandi dan Gregorius Candra .(2007). Service, Quality, and Satisfacation. Yogyakarta: Andi Offset

[7] Umar, Husain. 2005. Studi Kelayakan Dalam Bidang Jasa. Jakarta: Cetakan 1. Jakarta: Gramedia Pustaka Utama.

[8] Yamit, Zulian. 2005. Manajemen Kualitas Produk dan Jasa. Edisi Pertama, Cetakan Keempat, Penerbit Ekonisia, Kampus Fakultas Ekonomi UII Yogyakarta.

[9] Nurgaha Lutfi, Yuniar, dan Ambar Harsono. 2015. "Usulan Peningkatan Kualitas Pelayanan JasaPendidikan Bahasa Inggris MenggunakanMetode Service Quality(Servqual)Di Lbpp Lia MartadinataKota Bandung”. Vol. 3, No. 1. ISSN: 2338-5081

[10] Martilla, J. A. James. 1997. Importance-Performance Analysis. Journal Of Marketing 41 Pp 13-17

[11] Parasuraman, A, Zeithml, Valarie A. And Berry, Leonard L . 1991 Refinement and Reassessment of the SERVQUAL Scale. Journal of retailing, Vol 67, No.4:420-450

[12]Rosi, Setyorini. 2015."Persepsi Mahasiswa Terhadap Kualitas Layanan Di Program Magister Sains dan Doktor Fakultas Ekonomika Dan Bisnis Universitas Gadjah Mada: Penerapan Model Servqual Gap5 Dan IPA”.Yogyakakarta: Tesis UGM.

[13] Wibisono, Deni. 2018. "Analisis Kualitas Layanan PendidikanDengan Menggunakan IntegrasiMetode Servqual Dan QF”. Volume 10, No. 1, pp. 56-74 e-ISSN: 2502-5449 p-ISSN: 2085-2266

[14] https://jabar.bps.go.id/statictable/2018/03/12/293/jumlah-perguruan-tinggi-swasta-di-lingkungankopertis-wilayah-iv-menurut-kabupaten-kota-se-jawa-barat-2017.html[di akses tanggal 08 Agustus 2019 jam 20:36 wib]

[15] http://junaidichaniago.wordpress.com[di akses tanggal 16 Agustus 2019 jam 15:58 wib] 